\title{
Earthworms as a biological control agent of nematode parasites of small ruminants
}

\author{
Séverine D'Alexis ${ }^{1}$, Axelle Simphor ${ }^{1}$, Gladys Loranger-Merciris ${ }^{2}$ and Maryline Boval ${ }^{1+}$ \\ ${ }^{1}$ INRA, UR143, Unité de Recherches Zootechniques, domaine Duclos, 97170 Petit Bourg, Guadeloupe, France; ${ }^{2}$ UAG, Fouillole, 97100 Pointe à Pitre, Guadeloupe, France
}

\section{Introduction}

Internal parasitism constitutes one of the greatest limiting factors of the grazing livestock production worldwide. Control of gastrointestinal nematodes is becoming a serious concern, particularly in the small ruminant industries, due to widespread and rapid development of resistance to anthelmintics. The research of alternative strategies could be focused on the free- living stages where nematode parasites are the most vulnerable to biotic factors. Of the latter, earthworms seem to be promising candidates for biological control of nematode parasites since infective larvae of gastrointestinal nematodes are located in dung and faecal organic matter, the main food source for several earthworms species. The aim of this study was to assess the effect of a mixed population of indigenous earthworms (Pontoscolex corethrus and Perionyx excavatus) on the count and proportion of GIN larvae of Haemonchus contortus and Trichostrongylus colubriformis recovered in faeces of naturally infected Creole goats.

\section{Materials and Methods}

Forty aluminium containers were filled with $400 \mathrm{~g}$ of ground ferralitic soil, dried and sieved to eliminate plant remains and large invertebrates before the addition of earthworms. Two levels ( 0 vs 14 individuals per container) of indigenous earthworms ( $50 \%$ Pontoscolex corethrus and $50 \%$ Perionyx excavatus) were added to the containers. Faeces were collected from 20 grazing goats. Two $20 \mathrm{~g}$ samples per doe were randomly assigned to one of the following: (i) 1 of the 20 containers with earthworm or (ii) 1 of the 20 containers without earthworms, and were incubated for 7 days. Then the faeces not ingested were recovered and the numbers of free-living stages of each infective larvae species was identified to genus and counted at $40 \times$ magnification after a $24 \mathrm{~h}$ Baermann extraction. Data were normalized by a logarithmic transformation and then subjected to ANOVA with 20 replications using the GLM procedure of SAS.

\section{Results}

The addition of earthworms reduced by $34 \%(P<0.006)$ the number of infective larvae recovered in the faeces of goats (Table 1$)$. The reduction was significant for both larvae species, $29 \%$ and $33 \%$ for $H$. contortus and $T$. colubriformis, respectively. The ratio of the two species of larvae, without or with earthworms, did not vary significantly $(P>0.21)$.

Table 1 Arithmetic means of infective larvae of two GIN, Haemonchus contortus and Trichostrongylus colubriformis, recovered from containers in which faeces were kept with two species of earthworms Pontoscolex corethrurus and Perionyx excavatus (treatment) or without (control)

\begin{tabular}{lcccc}
\hline \hline Strongyle species & Without earthworms & With earthworms & Treatment effect $P$ & Animal effect $P$ \\
\hline HT & 66 & 43 & 0.006 & $<0.01$ \\
H & 31 & 22 & 0.02 & $<0.01$ \\
T & 30 & 20 & 0.027 & $<0.01$ \\
Ratio HT & 1.01 & 1.14 & 0.21 & $<0.01$ \\
\hline \hline
\end{tabular}

HT: H. contortus + T. colubriformis; H: H. contortus; T: T. colubriformis.

\section{Discussion}

The results of the present study suggest that the indigenous earthworms may markedly reduce the populations of the two GIN larvae examined. This reduction is probably due to the consumption by the earthworms of the larvae at the same time as the dung ( $P$. excavatus) and soil $(P$. corethrurus). A reduction of $34 \%$ is worthy to note and may be an effective way to reduce the parasitism on pasture. This reduction ratio must be confirmed in situ, on pasture, but a $30 \%$ reduction may significantly decrease contamination of the pasture, and therefore the subsequent larval intake by grazing animals.

Moreover some earthworm species also seem to be promising candidates for vermicomposting i.e. the stabilization of organic materials such as animal wastes, agricultural residues and industrial wastes, through the action of earthworms. Compared to the conventional

\footnotetext{
${ }^{\dagger}$ E-mail: Maryline.Boval@antilles.inra.fr
} 
composting system, the vermicomposting often results in mass reduction, shorter time for processing and a better quality end-product (vermicompost) in terms of nutrient avaibility and levels of humus (Suthar, 2008).

\title{
Conclusion
}

Thus the use of earthworms may reduce parasitism and improve forage quality in tropical pastures. These results must be confirmed in experiments on pasture, with other ratios and combinations of earthworms.

\section{Acknowledgement}

The authors want to thank Duclos and Gardel experiment unit staff directed by Harry Archimède, for experiment management and lab work. This work has been partly supported by the European Union (FSE) and Guadeloupe Region.

\section{Reference}

Suthar S 2008. Bioconversion of post harvest crop residues and cattle shed manure into value-added products using earthworm Eudrilus eugeniae Kinberg. Ecological Engineering 32 (3), 206-214.

\section{Parasitic Infections in Association with Serum Copper, Phosphorus, and Heamatological values in sheep and goats of Swayback prone farms Central Trinidad}

\author{
A. Mohammed ${ }^{1 \dagger}$, M. Campbell ${ }^{2}$ and F. G. Youssef ${ }^{3}$ \\ ${ }^{1}$ The University of Trinidad and Tobago, lot 74-98 O'Meara Industrial Park, Arima Trinidad; ${ }^{2}$ School of Veterinary Medicine, Faculty of Medical Sciences U.W.I., Mt. \\ Hope, Trinidad, West Indies; ${ }^{3}$ Department of Food Production, The University of the West Indies, St. Augustine, Trinidad, West Indies
}

\section{Introduction}

Coccidian and gastrointestinal nematode infections as mixed or single infections are major parasitic diseases affecting health and productivity of the sheep and goat industry in both tropical and temperate climates. Controlled dosing studies of gastrointestinal parasites in sheep have shown an association between parasitic infection and depressed blood $\mathrm{Cu}$ and $\mathrm{P}$ levels. Although the economic significance of these conditions is speculated upon, no field study has been done in Trinidad to demonstrate whether parasitic infections and Cu and P deficiencies occur concurrently and their importance to the sheep and goat industry of Trinidad.

Initially, a study was done to investigate two outbreaks $(1987,89)$ of a suspected Copper $(\mathrm{Cu})$ deficiency condition swayback resulting in high mortality in grazing sheep and goats of rural farms and intensively reared animals of three government owned farms of Central Trinidad. Initial findings from blood serum of 131 sheep and 86 goats of a fixed sampling survey of affected farms indicated that more than $80 \%$ and $50 \%$ of swayback affected and apparently normal animals combined had low Cu levels $\left(<0.65 \mathrm{mg} \mathrm{L}^{-1}\right)$ and $P\left(<45 \mathrm{mg} \mathrm{L}^{-1}\right)$ (Mohammed, 1999).

The study presented here sought to investigate the possible association between parasitic infections, serum Copper, Phosphorus and haematological values in sheep and goats of affected and apparently normal animals combined from swayback prone farms.

\section{Materials and Methods}

Single faecal, whole and clotted blood samples were taken from one month to four year old sheep $(n=66 / 131)$ and goats $(n=66 / 86)$ from swayback prone farms. On the whole, blood and faecal samples, complete blood counts and the degree of parasitic infection were determined manually for the former and diagnostically by the number of eggs/ova per microscopic field $(1+, 2+, 3+, 4+)$ for the latter. Total protein, fibrinogen, Copper $(\mathrm{Cu})$ and Phosphorus $(\mathrm{P})$ concentrations in plasma and serum were determined by heat precipitation, atomic absorption and colorimetrically, respectively. Data were analysed using a one way ANOVA.

Results

Fifty-five percent of sheep and $85 \%$ of goats displayed a mild to moderate degree of mixed parasitic infections $(1+-3+)$. Haemoglobin, PCV, and $\mathrm{Cu}$ values varied significantly $(P<0.05)$ with the degree of parasitic infection in goats and slightly in sheep $(P<0.07,0.05)$. Lower $\mathrm{Hb}$

\footnotetext{
†E-mail: aphzal.mohammed@utt.edu.tt
} 